\title{
Influence of Synchronization Techniques on Nicking in Parental Lines of Pearl Millet Hybrid BPMH-3 Seed Production
}

\author{
M. Priyanka*, K. Shruthi and R. Gurumurthy \\ Department of Seed Science and Technology, University of Agricultural Sciences \\ Dharwad - 580005, Karnataka, India \\ *Corresponding author
}

\section{Keywords \\ Synchronization, Seed setting, Test weight, Seed yield \\ Article Info \\ Accepted: \\ 10 October 2018 \\ Available Online: \\ 10 November 2018}

\section{A B S T R A C T}

A field experiment was carried out during Kharif 2016 at the Main Agricultural Research Station, University of Agricultural Sciences, Dharwad to investigate the effect of staggered sowings and application of additional dose of nitrogen to late parent on synchronization of male and female parents of pearl millet hybrid BPMH-3. The field experiment comprised of twelve treatments with three replications in split plot design. The results revealed that staggered sowing of male parent nine days earlier than female $\left(\mathrm{S}_{4}\right)$ took less number of days for 50 per cent flowering in male (66.33 days) and also recorded the highest seed set per cent $(78.10 \%)$, test weight $(9.90 \mathrm{~g})$ and seed yield per plant $(21.01 \mathrm{~g})$ compared to other staggered sowings. On the other hand simultaneous sowing of female and male parent recorded the lowest values for growth parameters and it took more number of days to 50 per cent flowering $\left(S_{1}: 67.44\right)$ and recorded least seed set percent, test weight and seed yield per plant viz. $61.08 \%, 7.04 \mathrm{~g}$ and $18.43 \mathrm{~g}$ respectively. With respect to application of additional dose of nitrogen $(\mathrm{N})$, recommended dose of fertilizer $\left(\mathrm{N}_{0}\right)$ recorded least seed set percent, test weight and seed yield per plant $(62.77 \%, 8.00 \mathrm{~g}$ and $18.82 \mathrm{~g}$ respectively). While, $\mathrm{N}_{2}$ : Application of additional $\mathrm{N} @ 10 \mathrm{~kg} \mathrm{ha}^{-1}$ at $35 \mathrm{DAS}$ to late parent recorded less number of days for fifty per cent flowering (65.92days) and the highest seed set percent $(73.26 \%)$, test weight $(8.68 \mathrm{~g})$ and seed yield per plant $(20.53 \mathrm{~g})$. Further the combination of staggered sowing of male parent by nine days earlier than female parent coupled with the application of additional dose of nitrogen @ $10 \mathrm{~kg} \mathrm{ha}^{-1}$ at 35 days after sowing to male parent $\left(\mathrm{N}_{2}\right)$, decrease the difference in flowering between female and male parent to -0.74 days $\left(\mathrm{S}_{4} \mathrm{~N}_{2}\right)$ from 11.00 days $\left(\mathrm{S}_{1} \mathrm{~N}_{0}\right)$. This revealed that sowing of male parent nine days earlier than the female parent and application of additional $10 \mathrm{~kg} \mathrm{~N} \mathrm{ha}^{-1}$ to male parent at 35 days after sowing was appropriate to achieve nicking between female and male parental lines of pearl millet hybrid, BPMH-3.

\section{Introduction}

Pearl millet (Pennisetum glaucum) in India is known by several names in different languages, commonly called as bajra, cumbu, sajje etc. and it is also called as cattle millet, bulrush millet or candle millet. It belongs to family Gramineae (poaceae). Pearl millet seed contains $11.8 \mathrm{~g}$ proteins, $4.8 \mathrm{~g}$ fat, $2.3 \mathrm{~g}$ fiber, $67 \mathrm{~g}$ carbohydrate and minerals like calcium (16mg), iron (6mg), magnesium (228mg), phosphorous (570mg), sodium (10mg), zinc 
(3.4mg), potassium (390mg), copper $(1.5 \mathrm{mg})$ and manganese (33mg).

Area under pearl millet cultivation in Karnataka is 0.29 mha, production of $0.31 \mathrm{~m}$ tons and productivity of $1080 \mathrm{kgs} / \mathrm{ha}$ (Annon, 2014). Mainly pearl millet is grown on marginal lands under harsh condition with limited use of chemicals and fertilizers. Besides this, the quality seed of improved genotypes is another major constraint to enhance production, productivity, seed replacement rate and also loss of crop due to downy mildew disease. Though the yielding potential of pearl millet is good, there is a wide gap exists between potential yield and natural yield. Hence with the establishment of AICRIP in pearl millet in 1961 by ICAR, New Delhi, the exploitation of heterosis was initiated, as a result of this first hybrid of pearl millet (HB-1) was released by AICRIP in1965.

Among the production factors, major barrier in hybrid seed production is to achieve proper nicking between female and male parental lines and the non-uniformity in flowering period of male and female parent results in poor seed set mainly due to non-availability of pollen at the time of stigma receptivity in female parent due to the protogyny. To achieve proper synchronization of flowering of male and female parents during hybrid seed production, the methods like staggered planting, chemical methods and cultural practices such as application of additional dose of nitrogen through soil, spraying of urea, gibberellic acid, ABA, hydro priming and controlled irrigation are followed.

The pearl millet hybrid BPMH-3 is a cross between ICMA $9277 \times$ TPRT 111. The female parent (ICMA 9277) flowers earlier than male parent (TPRT 111). The period of staggered sowings in hybrid seed production of pearl millet can be reduced amicably by application of additional dose of nitrogen to late parent so that the late flowering parent meet synchrony and facilitate the simultaneous flowering which otherwise difficult under a longer period of staggered sowing. In the past, several methods have been adopted to overcome the problem of non-synchronization of flowering. When the difference in flowering between parental lines is more than the marginal, the only alternative is staggered planting which is not in practice in pearl millet hybrid. In staggered planting, the planting dates of parental lines of hybrid is adjusted to make them to flower at the same time but the success mainly depends on the information about the flowering behaviour of both the parents across the locations during different seasons, as inter planting of parental lines in definite row ratios is involved in pearl millet hybrid seed production. Since pearl millet is nitro positive crop, increase in the doses of nitrogen application has been practiced to hasten the flowering which also enables the parental lines to bridge the marginal gap in the flowering period. The flowering behaviour could also be manipulated by the use of different chemicals like gibberellic acid, foliar spray of nitrogen, phosphorus and pre-sowing hydration, which hasten the flowering. Hence, in the present investigation efforts were made to achieve synchrony between parental flowering where flowering of male parent is 11 days later compared to the female parent.

\section{Materials and Methods}

The field experiment was conducted during Kharif2016 at Main Agricultural Research Station (MARS), UAS Dharwad, which is situated at $15^{\circ} 12^{\prime} \mathrm{N}$ latitude and $76^{\circ} 34^{\prime} \mathrm{E}$ longitude with an altitude of $678 \mathrm{~m}$ above mean sea level. The experimental site consisted of medium deep black soil. The field experiment was laid out in a split plot design with two factors, Factor - I: Staggered sowing (S), Factor - II: application of additional dose 
of nitrogen to male parent $(\mathrm{N})$. Main factor consisting of sowing of male line at different dates i.e. $\mathrm{S}_{1}$ : Simultaneous sowing of both the parents, $\mathrm{S}_{2}$ : Staggered sowing of late parent (male) 3days earlier to female, $S_{3}$ : Staggered sowing of late parent (male) six days earlier to female and $\mathrm{S}_{4}$ : Staggered sowing of late parent (male) nine days earlier to female. While, sub plots of application of additional dose of nitrogen to male parent consisted of $\mathrm{N}_{0}$ : Recommended dose of fertilizer (100:60:25NPK, kg/ha), $\mathrm{N}_{1}$ : Additional $10 \mathrm{~kg} / \mathrm{ha} \mathrm{N}$ application 30 days after sowing and $\mathrm{N}_{2}$ : Additional $10 \mathrm{~kg} / \mathrm{ha} \mathrm{N}$ application 35days after sowing.

The observations on days to $50 \%$ flowering, seed setting percentage, test weight $(\mathrm{g})$ and seed yield per plant (g) were recorded at respective stages.

\section{Results and Discussion}

The experimental results indicated that, delay in days to $50 \%$ flowering in $\mathrm{S}_{4} \mathrm{~N}_{2}(65.00$ days) treatment combination (Table 1). Among the staggered sowings, $\mathrm{S}_{4}$ recorded less number of days for 50 per cent flowering. Further, seed set percent, test weight and seed yield per plant differed significantly with staggered sowings and application of additional dose of nitrogen (Table 2).

Significant differences were observed for days to 50 per cent flowering due to staggered sowings irrespective of application of additional dose of nitrogen. However, the sowing of male parent 9 days before female parent $\left(\mathrm{S}_{4}\right)$ took relatively shorter period (66.33 days) for 50 per cent flowering as compared to sowing of female and male parent on same day $\left(\mathrm{S}_{1}: 67.44\right.$ days $)$ and reduced the difference in flowering between female and male parent from 10.55 to 0.89 days. The results indicated significant effect on flowering parameters due to staggered sowings. These findings are also in conformity with the results of Biradar Patil (1984) and Shivappa (1988) in sorghum hybrid seed production, Tanwir Alam et al., (2007) in maize hybrid and Dhedhi et al., (2007) in Bajra.

Irrespective of staggered sowings, application of additional dose of nitrogen revealed significant variation on flowering parameters. However, number of days taken to 50 per cent flowering was relatively less $(65.92)$ at $10 \mathrm{~kg}$ $\mathrm{N}$ at 35 DAS. This may be due to increase in plant height and more number of leaves leading to faster growth of reproductive structures. Further, it was also related to greater availability and translocation of photosynthates at the metabolizing zone and it hastened flowering behaviour of the plants due to additional application of nitrogen levels at 35DAS. Similar findings were also reported by Pandusastry (1981) in CSH-5 and Shivappa (1988) in DSH-1 sorghum hybrid, Dhedhi et al., (2006) in bajra, Tanwir Alam et al., (2007) in maize.

The interaction effect between staggered sowings and application of additional dose of nitrogen $(\mathrm{SxN})$ showed significant variation for days to 50 per cent flowering. However, the treatment combination of sowing of male parent 9 days before female sowing along with application of $10 \mathrm{~kg} / \mathrm{ha}$ additional nitrogen to late parent took relatively less number of days (65.0days) for 50 per cent flowering as compared to the simultaneous sowing of male and female parents and application of recommended dose of fertilizer $\left(\mathrm{S}_{1} \mathrm{~N}_{0}\right)$ took 68.33days.

Significant differences for hybrid seed yield and yield components like seed set per cent, test weight and seed yield per plant was observed due to staggered sowings and application of additional dose of nitrogen to late parent. 
Table.1 Days to 50 flowering in Female parent (ICMA 9277) and male parent (TPRT 111) as influenced by staggered sowing and application of additional dose of nitrogen to late parent (restorer line)

\begin{tabular}{|c|c|c|c|}
\hline Treatments & \multicolumn{3}{|c|}{ Days to 50 flowering (days) } \\
\hline Main plot : Staggered sowings (S) & $\begin{array}{c}\text { Female } \\
\text { parent (Seed } \\
\text { parent) }\end{array}$ & $\begin{array}{l}\text { Male parent } \\
\text { (Restorer line) }\end{array}$ & $\begin{array}{l}\text { Difference } \\
\text { (days) }\end{array}$ \\
\hline$S_{1}$ : Simultaneous sowing of both the parents & 56.89 & 67.44 & 10.55 \\
\hline $\begin{array}{l}S_{2} \text { : Staggered sowing of late parent (male) three days } \\
\text { earlier to female }\end{array}$ & 56.44 & $67.22(-3)$ & 7.78 \\
\hline $\begin{array}{l}S_{3}: \text { Staggered sowing of late parent (male) six days } \\
\text { earlier to female }\end{array}$ & 57.00 & $67.33(-6)$ & 4.33 \\
\hline $\begin{array}{l}\mathrm{S}_{4} \text { : Staggered sowing of late parent (male) nine days } \\
\text { earlier to female }\end{array}$ & 56.44 & $66.33(-9)$ & $\overline{0.89}$ \\
\hline Mean & 56.69 & 67.08 & - \\
\hline S.Em. \pm & 0.63 & 0.14 & \\
\hline C.D. $(P=0.05)$ & NS & 0.42 & \\
\hline $\begin{array}{l}\text { Sub plot: Application of additional doses of nitrogen to } \\
\text { late parent }(\mathbf{N})\end{array}$ & & & \\
\hline $\begin{array}{l}\mathrm{N}_{0}: \text { Recommended dose of fertilizer }\left(100: 60: 25 \mathrm{~kg} \mathrm{ha}^{-1}\right) \\
\text { only }\end{array}$ & 57.17 & 68.08 & 10.91 \\
\hline $\mathrm{N}_{1:}$ Application of additional N @ $10 \mathrm{~kg} \mathrm{ha}^{-1}$ at $30 \mathrm{DAS}$ & 56.83 & 67.25 & $10.42(-0.42)$ \\
\hline $\mathrm{N}_{2}$ : Application of additional N @ $10 \mathrm{~kg} \mathrm{ha}^{-1}$ at $35 \mathrm{DAS}$ & 56.08 & 65.92 & $9.84(-1.07)$ \\
\hline Mean & 56.69 & 67.08 & - \\
\hline S.Em. \pm & 1.39 & 0.16 & \\
\hline C.D. $(P=0.05)$ & NS & 0.50 & \\
\hline Interactions (SXN) & & & \\
\hline $\mathbf{S}_{1} \mathbf{N}_{0}$ & 57.33 & 68.33(-0) & 11 \\
\hline $\mathbf{S}_{1} \mathbf{N}_{1}$ & 57.00 & $67.67(-0.49)$ & 10.18 \\
\hline $\mathbf{S}_{1} \mathbf{N}_{2}$ & 56.33 & $66.33(-1.07)$ & 8.93 \\
\hline $\mathbf{S}_{2} \mathbf{N}_{0}$ & 57.00 & $68.00(-3)$ & 8 \\
\hline $\mathbf{S}_{2} \mathbf{N}_{1}$ & 56.33 & $67.33(-3.49)$ & 7.51 \\
\hline $\mathbf{S}_{2} \mathbf{N}_{2}$ & 56.00 & $66.00(-4.07)$ & 5.93 \\
\hline $\mathbf{S}_{3} \mathbf{N}_{0}$ & 57.33 & $68.33(-6)$ & 5 \\
\hline $\mathbf{S}_{3} \mathbf{N}_{1}$ & 57.33 & $67.33(-6.49)$ & 3.51 \\
\hline $\mathbf{S}_{3} \mathbf{N}_{2}$ & 56.33 & $66.33(-7.07)$ & 2.93 \\
\hline $\mathbf{S} \mathbf{S}_{\mathbf{N}} \mathbf{N}_{\mathbf{0}}$ & 57.00 & $67.67(-9)$ & 1.67 \\
\hline $\mathbf{S}_{4} \mathbf{N}_{1}$ & 56.67 & $66.33(-9.49)$ & 0.17 \\
\hline $\mathbf{S}_{4} \mathbf{N}_{2}$ & 55.67 & $65.00(-10.07)$ & -0.74 \\
\hline Mean & 56.69 & 67.08 & - \\
\hline$\overline{\text { S.Em. } \pm}$ & 0.18 & 0.48 & \\
\hline C.D. $(P=0.05)$ & NS & 1.47 & \\
\hline
\end{tabular}

NS: Non significant 
Table. 2 Seed set per cent, test weight and seed yield per plant in $\mathrm{F}_{1}$ of BPMH-3 as influenced by staggered sowing and application of additional dose of nitrogen to late parent (restorer line)

\begin{tabular}{|c|c|c|c|}
\hline Treatments & \multicolumn{3}{|c|}{ F 1 (ICMA 9277 x TPRT 111) } \\
\hline Main plot : Staggered sowings (S) & $\begin{array}{l}\text { Seed set } \\
(\%)\end{array}$ & $\begin{array}{c}\text { Test weight } \\
\left(\text { g } 1000^{-10 e d s^{-1}}\right)\end{array}$ & $\begin{array}{l}\text { Seed yield } \\
\left(\text { g plant }^{-1}\right)\end{array}$ \\
\hline $\mathbf{S}_{\mathbf{1}}$ : Simultaneous sowing of both the parents & 61.08 & 7.04 & 18.43 \\
\hline $\begin{array}{l}\mathbf{S}_{2}: \text { Staggered sowing of late parent (male) three days } \\
\text { earlier to female }\end{array}$ & 65.40 & 8.03 & 19.17 \\
\hline $\begin{array}{l}S_{3}: \text { Staggered sowing of late parent (male) six days } \\
\text { earlier to female }\end{array}$ & 69.28 & 8.46 & 20.02 \\
\hline $\begin{array}{l}S_{4}: \text { Staggered sowing of late parent (male) nine days } \\
\text { earlier to female }\end{array}$ & 78.10 & 9.90 & 21.01 \\
\hline Mean & 68.46 & 8.36 & 19.66 \\
\hline S.Em. \pm & 1.83 & 0.40 & 0.30 \\
\hline C.D. $(P=0.05)$ & 5.49 & 1.19 & 0.9 \\
\hline $\begin{array}{l}\text { Sub plot: Application of additional doses of nitrogen to } \\
\text { late parent(N) }\end{array}$ & & & \\
\hline $\begin{array}{l}\mathrm{N}_{0} \text { : Recommended dose of fertilizer }\left(100: 60: 25 \mathrm{~kg} \mathrm{ha}^{-1}\right) \\
\text { only }\end{array}$ & 62.77 & 8.00 & 18.82 \\
\hline $\mathrm{N}_{1:}$ Application of additional N @ $10 \mathrm{~kg} \mathrm{ha}^{-1}$ at $30 \mathrm{DAS}$ & 69.37 & 8.39 & 19.62 \\
\hline $\mathrm{N}_{2}$ : Application of additional N @ $10 \mathrm{~kg} \mathrm{ha}^{-1}$ at $35 \mathrm{DAS}$ & 73.26 & 8.68 & 20.53 \\
\hline Mean & 68.46 & 8.36 & 19.66 \\
\hline S.Em. \pm & 1.23 & 0.11 & 0.13 \\
\hline C.D. $(P=0.05)$ & 3.79 & 0.34 & 0.39 \\
\hline Interactions (SXN) & & & \\
\hline $\mathbf{S}_{1} \mathbf{N}_{0}$ & 60.24 & 6.67 & 17.73 \\
\hline $\mathbf{S}_{1} \mathbf{N}_{1}$ & 61.00 & 7.17 & 18.10 \\
\hline $\mathbf{S}_{1} \mathbf{N}_{2}$ & 62.00 & 7.30 & 19.47 \\
\hline $\mathbf{S}_{2} \mathbf{N}_{0}$ & 60.50 & 8.00 & 18.17 \\
\hline $\mathbf{S}_{2} \mathbf{N}_{1}$ & 67.03 & 8.00 & 19.13 \\
\hline $\mathbf{S}_{2} \mathbf{N}_{2}$ & 68.67 & 8.10 & 20.20 \\
\hline $\mathbf{S}_{3} \mathbf{N}_{0}$ & 60.67 & 8.27 & 19.50 \\
\hline $\mathbf{S}_{3} \mathbf{N}_{1}$ & 69.83 & 8.40 & 20.23 \\
\hline$S_{3} \mathbf{N}_{2}$ & 77.33 & 8.70 & 20.33 \\
\hline $\mathrm{S}_{\mathbf{4}} \mathbf{N}_{\mathbf{0}}$ & 69.67 & 9.07 & 19.89 \\
\hline $\mathbf{S}_{\mathbf{4}} \mathbf{N}_{\mathbf{1}}$ & 79.61 & 10.00 & 21.00 \\
\hline $\mathbf{S}_{4} \mathbf{N}_{2}$ & 85.03 & 10.63 & 22.13 \\
\hline Mean & 68.46 & 8.36 & 19.66 \\
\hline S.Em. \pm & 3.53 & 0.32 & 0.37 \\
\hline C.D. $(P=0.05)$ & 10.70 & 0.98 & 1.11 \\
\hline
\end{tabular}

NS: Non significant 
Among the different staggered sowings, the sowing of male parent 9 days before female parent $\left(\mathrm{S}_{4}\right)$ recorded significantly higher seed set per cent (78.10), test weight $(9.90 \mathrm{~g} / 1000$ seeds) and seed yield per plant (21.01g) over control i.e. simultaneous sowing of female and male parent $\left(\mathrm{S}_{1}: 61.08 \%, 7.04 \mathrm{~g}\right.$ and $18.43 \mathrm{~g} /$ plant respectively). This increase in the hybrid seed yield might be attributed to smaller differences in days to 50 per cent flowering noticed between the female and male parents this has caused better synchronization of flowering due to more availability of viable pollens at peak flowering period resulting in higher hybrid seed yield components like seed set per cent, test weight and seed yield per plant as compared to simultaneous sowing of female and male parent which recorded less hybrid seed yield. This may be related to wider differences in days to 50 per cent flowering noticed between female and male parent causing non synchronization of flowering and lack of availability of ample viable pollens at peak flowering period resulted in less seed setting as well as hybrid seed yield. These findings are in agreement with those of earlier researchers in sorghum hybrid seed production (Shivappa, 1988). Further, smaller differences in flowering between female and male parent resulted in good synchronization of flowering between parents on account of more availability of viable pollens. Hence, this resulted in the higher seed setting (78.10\%) and increased hybrid seed yield components as evident from the results of this study. Similar positive results of plant nutrients on hybrid seed yield components was also reported by Joshi (1976) and Patil (1978) in sorghum; Dhedhi et al., (2006) and Bhanuje (2012) in bajra and Varshney et al., (2006) and TanwirAlam et al., (2007) in maize.

The interaction effect between staggered sowing and application of additional dose of nitrogen levels $(\mathrm{SxN})$ was found to be significant for hybrid seed yield and yield components. However, numerically more seed setting percentage $(85.03 \%)$, test weight (10.63 g) and hybrid seed yield per plant (22.13 g) were recorded by sowing male parent by 9 days earlier than female and with additional $10 \mathrm{~kg} / \mathrm{ha}$ application of $\mathrm{N}$ to male parent.

Closer synchronization of flowering between parents (ICMA 9277xTPRT 111) of hybrid pearl millet BPMH-3 could be obtained by sowing of male parent by 9 days earlier to female along with application of additional dose of nitrogen to late parent at 35DAS. Further, this treatment resulted in better yield components, higher seed yield and better seed quality traits.

\section{References}

Anonymous, 2014, Agricultural Statistics at a Glance, 2011, Ministry of Agriculture, Government of India.

Bhanuje, T., 2012, Synchronization studies in pearl millet hybrid MH-946 (GHB-558) seed production. M. Sc. (Agri.) Thesis, Univ. Agric. Sci., Dharwad, Karnataka (India).

BiradarPatil, N. K., 1984, Studies on effective methods for synchronization of flowering in parents of DSH-1 hybrid sorghum. M.Sc. (Agri.) Thesis, Univ. Agric. Sci., Bangalore, (India).

Dhedhi, K. K., Dangaria, C. J, Prasanna, and Joshi, A. K., 2006, Synchronization of flowering in parental lines of bajra hybrid GHB-558. Agric. Sci. Digest, 27(2): 1582- 1583.

Joshi, M. K., 1976, Investigations on synchronization of flowering in CSH-5 hybrid sorghum seed production. $M$. Sc. (Agri.) Thesis, Univ. Agric. Sci., Bangalore, (India).

Pandusastry, K., 1981, Influence of 
agronomic practices on flowering behavior in parental lines of sorghum hybrid CSH-5. Ph.D. Thesis, Univ. Agric. Sci., Bangalore, (India).

Patil, R. C., 1978, Studies on seed production problems in hybrid sorghum CSH-8R. M. Sc. (Agri.) Thesis, Univ. Agric. Sci., Bangalore (India).

Shivappa, H., 1988, Studies on synchronization of flowering of parental lines in sorghum hybrid seed production of DSH-1 (CSH-10). M. Sc. (Agri.) Thesis, Univ. Agric. Sci., Dharwad,
(India).

TanwirAlam, Prasad S. K. and Vershney, S. K., 2007, Studies on synchronization of flowering in parental lines of Shaktiman-1 maize hybrid. Seed Res., 35(1): 99-101.

Varshney, TanwirAlam, Prasad, S. K. and Singh, B., 2006, Lack of synchrony of flowering: Barrier in Seed Production of Shaktiman-1 maize hybrid. In: XII Nat. Seed Sem., ANGRAU, Hyderabad, 2426 Feb. 2006, p. 52.

\section{How to cite this article:}

Priyanka, M., K. Shruthi and Gurumurthy, R. 2018. Influence of Synchronization Techniques on Nicking in Parental Lines of Pearl Millet Hybrid BPMH-3 Seed Production. Int.J.Curr.Microbiol.App.Sci. 7(11): 1223-1229. doi: https://doi.org/10.20546/ijcmas.2018.711.142 